\title{
NUTRITIONAL EVALUATION IN THE PERIOPERATIVE PERIOD OF GASTRIC CANCER PATIENTS USING BIOELECTRICAL IMPEDANCE ANALYSIS (BIA)
}

\author{
IVA KIRAC ${ }^{1}$, JANA FILA², ZVONIMIR MISIR ${ }^{3}$, JAKŠA FILIPOVIĆ ČUGURA ${ }^{3}$, \\ ANA ŽAJA ${ }^{4}$, IVANKA BENČIĆ ${ }^{1}$, LJILJA ŠTEFANČIĆ ${ }^{4}$ \\ ${ }^{1}$ Department of Surgical Oncology, University Hospital for Tumors, \\ Sestre milosrdnice University Hospital Center, Zagreb, Croatia; \\ ${ }^{2}$ Division of Diagnostic and Interventional Radiology, Department of Oncological Radiology, \\ University Hospital for Tumors, Sestre milosrdnice University Hospital Center, Zagreb, Croatia; \\ ${ }^{3}$ Department of Upper Gastrointestinal Surgery, Sestre milosrdnice University Hospital Center, \\ Zagreb, Croatia; \\ ${ }^{4}$ Department of Anesthesiology, Reanimation and Intensive Care Medicine, \\ University Hospital for Tumors, Sestre milosrdnice University Hospital Center, Zagreb, Croatia
}

\begin{abstract}
Summary
Gastric cancer is a 'neglected cancer,' with significant incidence (over 900 cases annually) and late-stage at the time of diagnosis in Croatia. Even in resectable cases, risk of malnutrition is high, and malnutrition-related to malignant disease presents a substantial problem in terms of compliance with treatment and complications during surgery. We retrospectively reviewed the patient records for patients operated for gastric cancer from January until December 2018. Data on sex, age, body mass index (BMI), complete preoperative blood count, postoperative recovery, and subsequent bioelectrical impedance analysis (BIA) measurements (preoperatively, on days 7, 14 and 30) were collected. All patients received nutritional support according to the Enhanced Recovery After Surgery (ERAS). Twenty-seven patients were operated for gastric cancer, eight were resected with curative intent (four total gastrectomies, one total gastrectomy with splenectomy, three distal gastrectomies and one local excision). Seven patients who had a resection were included in the perioperative nutritional protocol. All patients scored at risk according to Nutrition Score 2002 (NS2002). Two patients had tolerable initial BMIs and BIAs, only one patient with extremely low BMI and BIA had prolonged intensive care unit (ICU) stay and difficulties with peroral nutrition. Only the patients with tolerable initial values recovered those values postoperatively in the observed period but did not improve. Lean body mass is lost before surgery, and in the early postoperative period, it takes up to 3 months to compensate. However, in the late stage of the disease, routine ERAS nutritional protocol seems not to be enough. Perhaps, in gastric cancer, a more aggressive parenteral perioperative nutrition might be an option.
\end{abstract}

KEYWORDS: gastric cancer, bioelectrical impedance analysis, prognostic nutritional score, ERAS

\section{NUTRITIVNA PROCIJENA BIOIMPEDANCIJOM (BIA) PACIJENATA S RAKOM ŽELUCA U PERIOPERACIJSKOM PERIODU}

Sažetak

Rak želuca je 'zanemareni rak', sa značajnom učestalošću (preko 900 slučajeva godišnje) i kasnom fazom u vrijeme dijagnoze u Hrvatskoj. Čak i u slučajevima koji se mogu resecirati, rizik od pothranjenosti je visok, a pothranjenost povezana s malignim bolestima predstavlja značajan problem u smislu pridržavanja liječenja i komplikacija tijekom liječenja. Od 
siječnja do prosinca 2018. retrospektivno smo pregledali podatke o bolesnicima koji su operirani zbog raka želuca. Podaci o spolu, dobi, indeksu tjelesne mase (BMI), potpunoj prijeoperacijskoj krvnoj slici, poslijeoperacijskom oporavku i mjerenjima bioimpedance (bioelectrical impedance analysis BIA), 7., 14. i 30. dan poslije operacije. Svi pacijenti dobili su nutritivnu potporu u skladu sa standardnim protokolom za oporavak (Enhanced Recovery After Surgery, ERAS). Dvadeset sedam bolesnika operirano je zbog raka želuca, 8 je resecirano s kurativnom namjerom (4 totalne gastrektomije, 1 totalna gastrektomija sa splenektomijom, 3 distalne gastrektomije i 1 lokalna ekscizija). Svi pacijenati koji su liječeni resekcijom bili su uključeni u perioperacijski prehrambeni protokol. Svi bolesnici su bili procijenjeni kao rizični za pothranjenost prema Nutrition Score 2002 (NS2002). Dvojica pacijenata su imala tolerabilne početne BMI-e i BIA-e, samo 1 bolesnik s ekstremno niskim vrijednostima BMI-a i BIA-e imao je produljeni boravak u jedinici intenzivnog liječenja i poteškoće s peroralnom prehranom. Samo su bolesnici s tolerabilnim početnim vrijednostima procijene ponovo dostigli te vrijednosti poslije operacije $\mathrm{u}$ promatranom razdoblju, ali ih nisu poboljšali. Mišićna masa se gubi prije operacije i u ranom poslijeoperacijskom razdoblju te je potrebno do 3 mjeseca za kompenzaciju. Međutim, u kasnom stadiju bolesti, rutinski ERAS protokol za prehranu se čini da nije dovoljan. Možda je kod raka želuca potrebna agresivnija parenteralna perioperacijska prehrana.

KLJUČNE RIJEČI: rak želuca, analiza bioelektrične impedancije, prognostički nutritioni rezultat, ERAS

\section{INTRODUCTION}

Gastric cancer is neglected cancer in Croatia. Sekerija described a decrease in both incidence and mortality of gastric cancer in the 20 year period, which is likely to continue due to change of nutritional habits and improved food storage (1). However, the number of new cases remains high 520 in males (mortality 478 cases) and 371 in female (mortality 323 cases) (2). Although complete surgical resection remains the only curative modality for early-stage gastric cancer, surgery alone only provides long-term survival in $20 \%$ of patients with the advanced-stage disease (3). Surgical treatment is either total gastrectomy or distal gastrectomy in most cases. Total gastrectomy might cause weight loss up to 6 months postoperatively, while in distal gastrectomy, patients' weight loss is usually up to 1 month (4). Cancer patients in the perioperative period first consume lean body mass (muscles). This might not be evident from body mass index nor nutritional scores alone (5). Therefore, we introduced the bioelectrical impedance analysis (BIA) in the perioperative nutritional protocol for gastrointestinal cancers. BIA is a device using weak electrical currents and measures resistance by calculating differences in voltage, indirectly semiquantitatively estimating body composition (fat, intra, and extracellular water and muscle/lean body mass)(5). Another tool we use is NS2002, which stratifies patients with increased risk based on the type of surgery and preoperative weight loss $(6,7)$.

Based on the values of these two estimations and complete blood count and biochemistry, we plan and adjust the perioperative nutritional support. In this paper, we looked into the results of these interventions on patients with gastric cancer resections.

\section{MATERIALS AND METHODS}

From 1st January 2018 until 31st December 2018, 27 patients were admitted to the Surgical Oncology department for clinically staged resectable gastric cancer. After explorative surgery, only 8 received resection with curative intent. NS2002 evaluation, complete blood count, and biochemistry body mass index and BIA were carried out preoperatively. Prognostic nutrition score was also calculated preoperatively. On postoperative days (POD) 7, 14, 30 and 90 BIA and if needed complete blood counts and biochemistry were recorded and prognostic nutrition index was calculated from preoperative values (8). Complications were recorded according to Gastrodata registry definitions (9).

\section{RESULTS}

Eight patients in the observed period had resection with curative intent. Five patients were male (average 65 years old), and 3 were females (average 62-year-old). All had NS2002 evaluation with increased risk. Two patients had tolerable preoperative BMI, and 2 did not complete the nutritional follow-up. Data on tumor histology, type of surgery, and BMI/BIA values are in Table 1. 
Table 1.

PATIENTS CHARACTERISTICS, AT LAST, FOLLOW UP 90 DAYS AFTER THE OPERATION.

\begin{tabular}{|l|l|l|l|l|l|l|l|l|l|}
\hline Patients & Age at operation /years & Sex & Type of surgery & Patology report & TNM & BMI & BIA/** & Complication & PNI \\
\hline P1 & 65 & M & TG & adenocarcinoma & pT3N3a & 25,1 & N/A & & 42,53 \\
\hline P2 & 57 & F & TG & adenocarcinoma & pT1bN1 & 21,9 & 4,9 & & 47,16 \\
\hline P3 & 79 & M & DG & adenocarcinoma & pT1N0 & 19 & 3,9 & & 38,35 \\
\hline P4 & 83 & M & DG & adenocarcinoma & pT4N3b & 17 & N/A & & 41,05 \\
\hline P5 & 63 & F & TG & adenocarcinoma & pT1aN0 & 23 & 5 & ** & 48,84 \\
\hline P6 & 65 & F & TG & adenocarcinoma & pT3N3 & 16,3 & 4 & **** & 46,74 \\
\hline P7 & 64 & M & TG+S & adenocarcinoma & pT3pN3a & 19,6 & 5,8 & & 47,85 \\
\hline P8 & 35 & M & E & GIST rec & & 19,7 & 5,4 & & 42,54 \\
\hline
\end{tabular}

*** prolong ICU stay patient with enteral nutrition difficulties; ${ }^{* *}$ revision on POD3 for hemorrhage control, * transfusion of red blood cells in ICU; TG - total gastrectomy, DG - distal gastrectomy, S - splenectomy, E - excision, PNI - prognostic nutritional index, N/A not available.

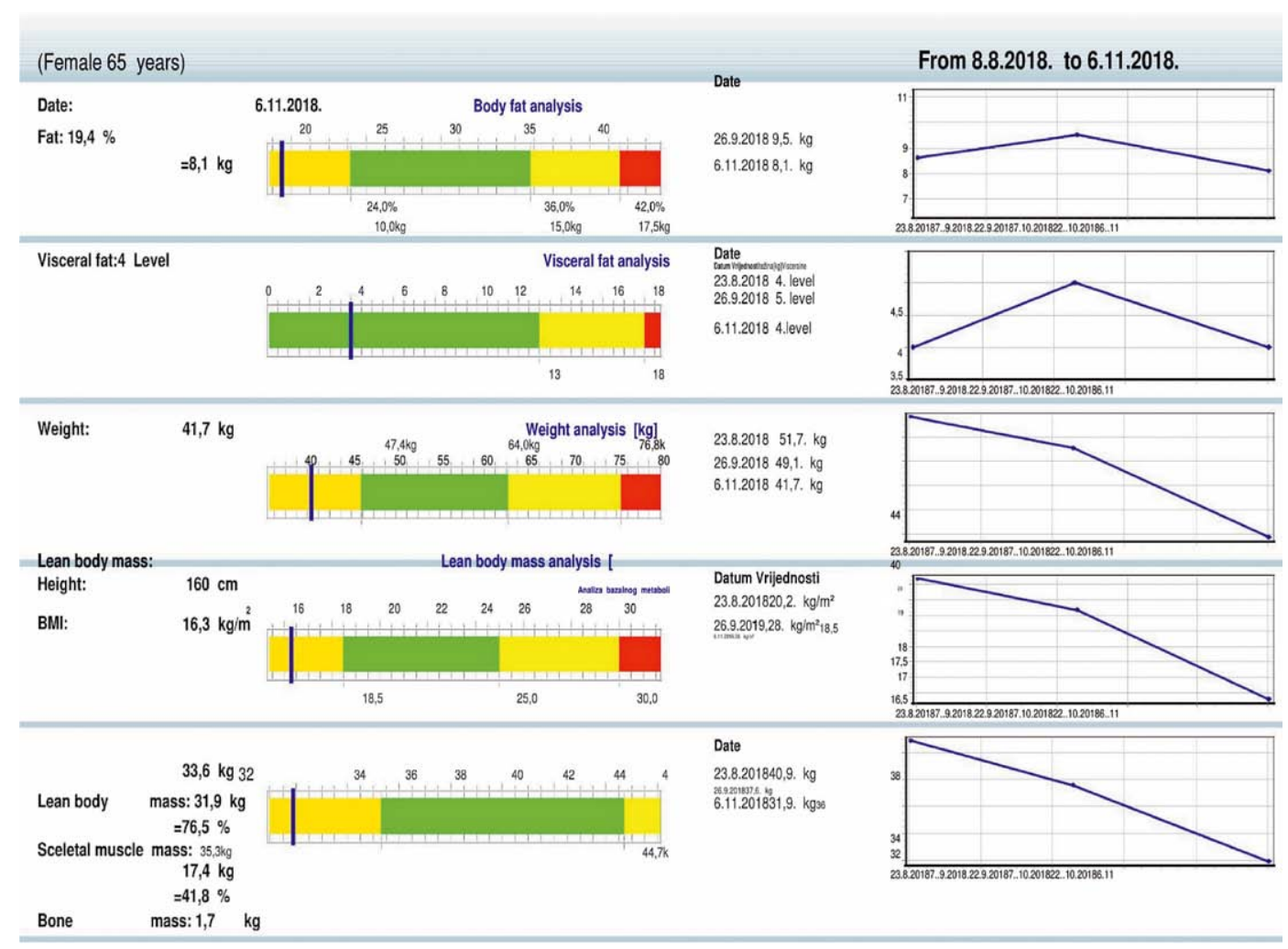

Figure 1. Bioelectrical impedance analysis report for P6 (patient with prolonged recovery).

\section{DISCUSSION}

Perioperative nutritional support is becoming an essential part of multidisciplinary cancer care. We have introduced a clinical pathway when we evaluate patients seven days before surgery and plan the nutritional support according to current European Society for Clinical Nutrition and Metabolism (ESPEN) guidelines with reevalua- tion $7,14,30$ and 90 days after surgery (10). To evaluate and follow the outcome, we also introduced a prognostic nutritional score and BIA. The number of patients eventually estimated was not sufficient to assess the value of PNI, but it seems significant that all our patients are under the threshold of lower morbidity and mortality rate. In the Lee cohort, showed promising results as a 
complication prediction tool, improved mortality and morbidity rates for the PNI above 52 .

On the other hand, BIA followed the trend of recovery and helped patients to visualize the effects of nutritional support and modifications thereof. In the observed time of 3 months, we did not observe the positive trend in any of our patients. For the ones with distal gastrectomy, the expected time to weight regain should be 6 months without specific intervention. ERAS protocol did not show the expected improvement in 3 months. Our numbers are limited. Furthermore, in 3 partial gastric resections, despite perioperative nutritional support, the first nutritional evaluation scores were very low. This might explain the lack of weight gain even after 1 month, which is expected to return to preoperative values. This probably reflected in hemostatic insufficiency in 2 malnourished patients, one needs a reoperation, while the other recovered on transfusion with erythrocyte (11). The second patient also had a delayed recovery of bowel function. An obvious drawback of this analysis is a small number of patients with resectable disease.

In Croatia, as well as in most of European Union, most gastric cancers are diagnosed in advanced stages. Moreover, those we believe are having a curative resection, end up being clinically understaged ( $40 \%$ in our series). Finally, patients we find and treat are found in late stages with malnutrition that cannot be reversed by adhering to current guidelines. A synergistic effort to find an optimal protocol for currently identified surgical candidates and Japanese or Korean strategy for earlier detection (accessible gastroscopy on first symptoms of discomfort) might improve the surgical treatment outcomes.

\section{CONCLUSION}

Gastric cancer is resectable in a fifth of newly diagnosed stages. Resection induces additional sarcopenia, along with preoperative loss due to gastric malignancy itself. Based on a rather small patients series, the current ERAS nutritional protocol was not enough to completely reverse these events. Adding parenteral pre/perioperative nutrition might be an option.

\section{REFERENCES}

1. Kirac I, Šekerija M, Šimunović I, Zgaga L, Vrdoljak DV, Kovacević D, et al. Incidence and mortality trends of gastric and colorectal cancers in Croatia, 1988-2008. Croat Med J. 2012;53(2):124-34.

2. Šekerija M, Bubanović L, Novak P, Šelendić Đ, Lončar J, Čukelj P. Registar za rak Republike Hrvatske. Incidencija raka u Hrvatskoj 2015. 2018;(40):1-44.

3. Proserpio I, Rausei S, Barzaghi S, Frattini F, Galli F, Iovino D, et al. Multimodal treatment of gastric cancer. World J Gastrointest Surg. 2014;6(4):55.

4. Davis JL, Selby L V, Chou JF, Schattner M, Ilson DH, Capanu M, et al. Patterns and Predictors of Weight Loss After Gastrectomy for Cancer. Ann Surg Oncol. 2016;23(5):1639-45.

5. Cohn SH, Gartenhaus W, Sawitsky A, Rai K, Zanzi I, Vaswani A, et al. Compartmental body composition of cancer patients by measurement of total body nitrogen, potassium, and water. Metabolism. 1981;30(3): 222-9.

6. Kondrup J, Rasmussen $\mathrm{HH}$, Hamberg O, Stanga Z, Ad Hoc ESPEN Working Group. Nutritional risk screening (NRS 2002): a new method based on an analysis of controlled clinical trials. Clin Nutr. 2003;22(3):321-36.

7. Detsky A, McLaughlin JR, Baker J, Johnston N, Whittaker S, Mendelson R, et al. What is subjective global assessment of nutritional status? J Parenter Enter Nutr. 1987;11(1):8-13.

8. Lee JY, Kim H-I, Kim Y-N, Hong JH, Alshomimi S, An JY, et al. Clinical Significance of the Prognostic Nutritional Index for Predicting Short- and Long-Term Surgical Outcomes After Gastrectomy: A Retrospective Analysis of 7781 Gastric Cancer Patients. Medicine (Baltimore). 2016;95(18):e3539.

9. Baiocchi GL, Giacopuzzi S, Marrelli D, Bencivenga M, Morgagni P, Rosa F, et al. Complications after gastrectomy for cancer: Italian perspective. Updates Surg. 2017;69(3):285-8.

10. Weimann A, Braga M, Carli F, Higashiguchi T, Hübner M, Klek S, et al. ESPEN guideline: Clinical nutrition in surgery. Clin Nutr. 2017;36(3):623-50.

11. Bick R. Coagulation Abnormalities in Malignancy: A Review. Semin Thromb Hemost. 1992;18(4):353-72.

Corresponding author: Iva Kirac, Department of Surgical Oncology, University Hospital for Tumors, Sestre milosrdnice University Hospital Center, Ilica 197, 10000 Zagreb, Croatia.e-mail: iva.kirac@kbcsm.hr 